\title{
Rеввавсн автіске: Soil properties and yield of sorghum-wheat sequence as affected by long term integrated nutrient management
}

\author{
B.G. RATHOD, S.R. PATIL, V.S. PATIL, R.P. ANDHLAE, A.B. DHAGE, P.P. \\ SABLE AND M.B. DHONDE
}

Article Chronicle: Received :

19.07.2017;

Accepted :

03.08.2017

KEY Words:

Integrated nutrient management, FYM, $\mathrm{pH}, \mathrm{EC}$, Organic carbon, Vertisols
SUMMARY : A permanent field experiment is continued since 1984-85 at AICRP on Integrated Farming System Research Farm, Mahatma Phule Krishi Vidyapeeth, Rahuri, Maharashtra with a view to find out the soil properties of sorghum [Sorghum bicolor (L.) Moench] -wheat (Triticum aestivum L.) crop sequence as affected by long term integrated nutrient management. The long term impact of integrated nutrient management on soil properties were studied after $32^{\text {nd }}$ cycle (2015-16). The treatment comprised different levels of recommended dose of fertilizers (RDF) viz., 50, 75, 100\% RDF in combination with and without farm yardmanure, wheat straw and green manure. The results indicated that, among the chemical properties soil $\mathrm{pH}$ and the electrical conductivity was recorded non-significant. The highest organic carbon percentage was observedin treatment receiving chemical fertilizers along with FYM. It was significantly improved $(0.71,0.69 \%)$ with the application of $50 \% \mathrm{NPK}+50 \% \mathrm{~N}$ through FYM $\left(\mathrm{T}_{6}\right)$ and lowest value $(0.44,0.41 \%)$ was observed in absolute control.The influence on soil properties ultimately reflected in higher yield of sorghum and wheat in the same treatment. It is also observed that the soil propertieswere significantly correlated with yield. Hence, it can be concluded that the use of 50\% NPK $+50 \% \mathrm{~N}$ through FYM is imperative for sustainable productivity and maintenance of soil fertility.

How to cite this article : Rathod, B.G., Patil, S.R., Patil, V.S., Andhlae, R.P., Dhage, A.B., Sable, P.P. and Dhonde, M.B. (2017). Soil properties and yield of sorghum-wheat sequence as affected by long term integrated nutrient management. Agric. Update, 12(TECHSEAR-7) : 1974-1977; DOI: 10.15740/HAS/AU/ 12.TECHSEAR(7)2017/1974-1977.
Author for correspondence :

\section{P.P. SABLE}

Department of Soil Science and Agricultural Chemistry, Mahatma Phule Krishi Vidyapeeth, Rahuri, AHMEDNAGAR (M.S.) INDIA

Email : sable.prasad7@ gmail.com

See end of the article for authors' affiliations 